\title{
Implementing Teachers' Training Technologies at a Federal University: E-portfolio, Digital Laboratory, PROLog Module System
}

\author{
https://doi.org/10.3991/ijoe.v15i04.9288 \\ Olga Smolyaninova ${ }^{\square}$, Ekaterina Bezyzvestnykh \\ Siberian Federal University, Krasnoyarsk, Russian Federation \\ ippssfu@mail.ru
}

\begin{abstract}
The paper describes the practice of the School of Education, Psychology and Sociology at Siberian Federal University on creating a contemporary digital learning environment for future teachers training, where the main units are LMS, MOODLE, e-portfolio, digital laboratory and PROLog module system of experiments. The research carried out in $2013-2017$ aims improving the quality of teachers training using e-learning, digital laboratory of scientific experiments modeling in elementary schools and e-portfolio assessment system.

The study has led to the development of model and methodological resources to use digital school subject laboratory. The students have mastered the set of e-learning tools (APM), which includes hardware, software and PROLog module system of experiments. The pilot projects on PROLog implementation in schools have been conducted during the students' teaching internship. Final reports are posted in the students' personal e-portfolios in the University's digital environment. This has brought 109 students of pedagogical specialization into the study. The research relies on the following methods: pedagogical modeling, observation, Google-forms, reflexive analysis of e-portfolios. Most students have demonstrated a high level of satisfaction and readiness to apply sophisticated digital resources in education. The survey of 63 teachers of the University and elementary school has evidenced the efficiency of PROLog module system in education. Remarkable body of the respondents (40\%) points out that the use of PROLog has improved the process of monitoring of research results among junior schoolchildren and allowed launching feedback net between the schoolchildren, students and teachers. Thus, the experiment confirms applicability of the considered teachers training technologies to solve the problem under our discussion. In this way, digital laboratory and PROLog module system of experiments together with e-training courses have ensured a rich digital environment in Federal University and leveled up the quality of contemporary teachers training.
\end{abstract}

Keywords-Digital education, e-learning, e-portfolio, PROLog module system of experiments, digital laboratory, Moodle, ICT competence. 


\section{Introduction}

The current modernization of education in the Russian Federation does not let teachers to explore digital resources, improve their ICT competence level in IT environment at high standards and in proper time. New educational technologies that can meet individual educational needs of students within mobility, variety of requests, multivariance and choice of learning content are required.

The most important tendencies related to the improvement of educational process quality are: information support; use of innovative ICT; teachers' ICT competence development.

There are two components which determine the possibility of IT trends realization: development and distribution of new information technologies and new educational practices [23].There are also two groups of factors that influence their implementation: external (developing conditions for using ICT in educational institutions) and internal (readiness and capability of educational institutions to implement new educational practices through the ICT). The main internal factors affecting the informational support of education, as stated in [41], [11], [1], [2] are the status of didactic issues (content definition, application of new methods and forms of education through the ICT, learning and teaching support materials, including e-learning resources); degree of teachers' ICT competence and dynamics of their professional development; teachers' aptitude and willingness to use new effective teaching practices provided by the ICT; flexibility of educational grade-rating system for formal, informal and nonformal education with electronic technologies and systems (LMS, e-portfolio, etc.); teachers' ability to identify and master the most effective organizational forms, methods and techniques in the ICT training.

One of the top projects of the Russian education system is "Modern Digital Educational Environment in the Russian Federation" [33]. The project (2018) is aimed at creating conditions for systematic upgrading and enriching opportunities for continuing education for all people through the development of the Russian digital educational system and increasing the number of students who would complete online courses up to 11 million people by the end of 2025. The main point of the project is to organize the access to online courses based on one-stop principle.

The issue of digital education in Russia is becoming more significant. Leading pedagogical universities of the Russian Federation represent the platforms for development and promotion of digital education [15]. In accordance with the UNESCO program "Information for all" [14], the main priorities of digital education are information literacy, information preservation, information availability, information ethics, information for development and linguistic variety in cyberspace.

I.V. Zhilavskaya [12] thinks that information means co-integration of media, mediation and communication. The information is being updated. According to this point of view, competencies have been formed under prevailing culture of linear information. Now they do not match the hyper-technological network society.

The development of modern digital education is connected with media and information literacy of students. In [22] we can note that there are parallelism and lack of interaction in the information training and media education development in Russia. 
Information training deals with PC capacities and use of ICT in searching for information and working with various types of papers. Especially it is designed for working with the papers related to educational and professional activity of students (educational, informative and scientific literature as well as their electronic versions). Media education is aimed at studying different types of media texts requiring special methods to analyze them, photo and video technology, film shooting and editing techniques. It develops perceptual skills and analysis of films and television programs, screen art language study, development of amateur journalism and video art.

The concept of digital education is connected with the trend on lifelong learning. Let us continue with the research results provided by National Research University "Higher School of Economics" [30]. The aim of the study was to assess the participation of adult population of the Russian Federation in various types of educational activities throughout the life - in formal education (professional education programs), additional education and self-education. Thus, about a half of the respondents were eager to improve their knowledge and skills needed in their professional activity; 14\% of the respondents mentioned the necessity for refresher courses, provided by the law or employer; $34 \%$ of respondents stand for a total development; $10 \%$ of respondents took up refresher courses because of the wage increase.

The most common type of educational activity is self-education with the use of printed materials (12.3\%). At the same time, the percentage of self - education through the Internet among Russians increases: in $2013-6.1 \%$, in $2014-7.4 \%$ [40], while through the refresher courses $-7.2 \%$.

In our observation, the most significant fact is the increasing number of those Russians who surf the materials on the Internet using mobile applications (for phones, tablets, etc.) and taking online courses or lectures $(2013-0.9 \%, 2014-2 \%)$ to educate themselves.

Recently, more attention has been paid to informational support given to different educational institutions (schools, colleges, universities) and development of teachers' ICT competence. The major students' activities are: ability to plan their activities; ability to find the information necessary for task-completing; projecting information model of object or process under the study; use of innovative ICT technologies for their personal and professional development.

\section{E-Learning Model of Siberian Federal University}

According to the Federal Law "On Education in the Russian Federation", elearning means management of educational activity with the information contained in databases. The information functions when implementing educational programs and it is processed by information technologies, hardware and software. This information is delivered through information and telecommunication networks which provide interaction between students and teachers, as stated in [10].

Since 2007 Siberian Federal University has implemented a project on e-learning realization. The regulations for the e-learning and distant learning technologies implementation at SibFU [34] were approved in 2017. The purpose of e-learning and 
distant learning technologies at SibFU is to provide modern conditions for the implementation of educational programs: increasing availability of the content and learning mode flexibility; involving students in the learning process: enriching opportunities for management and improving effectiveness of the educational process.

The current e-learning model of SibFU as stated in [8] is shown in Fig. 1.

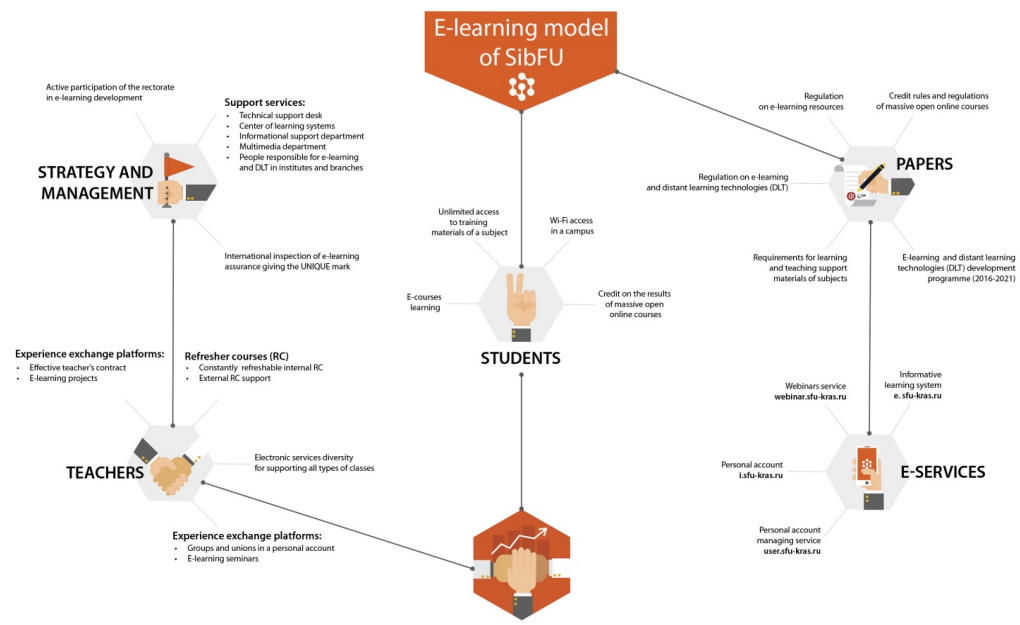

Fig. 1. E-learning model of SibFU

The information and educational environments are represented by the following resources:

- E-learning courses on the basis of LMS Moodle [9];

- Personal electronic portfolio [35], [37], [21];

- Massive open online courses [4];

- Unlimited Wi-Fi access;

- Personal account [31];

- Webinars and video conferences service [42];

- Personal account managing service [36].

The digital educational environment of the university develops according to the priority project "Modern Digital Educational Environment in the Russian Federation" and is supported by MOOC resources of the Russian Federation's open education platform [29] and e-portfolio technology. 


\section{Description of Using the Digital Environment at the Institute of Education, Psychology and Sociology (IEPS) at SibFU}

\subsection{E-portfolio technology}

E-portfolio is one of the leading innovative educational technologies successfully used in the teachers' training. It has been applied in educating students of pedagogical and psycho-pedagogical directions on bachelor's and master's degree programs since 2009. The experience and methods of using e-portfolio can be found in scientific publications [26] and monographs [25], educational journals [27] and proceedings of international conferences [28].

On the bachelor's degree program e-portfolio is used in training bachelors of pedagogical and psycho-pedagogical directions - the would-be tutors and teachers of developmental teaching according to Elkonin-Davydov system.

The main goals of using e-portfolio on this bachelor's degree program are:

- Motivation for achievements and educational results;

- Fixation and assessment of educational results in different courses;

- Interpretation of the results of first professional tests and teaching practice;

- Building of individual educational path;

- Guidelines for entering the master's degree program (exam in the form of portfolio).

The main goals of using e-portfolio on the master's degree program:

- Professional development;

- Reflection of professional practices (competency matrix);

- Introduction to potential employers;

- Demonstrations of research achievements;

- Guidelines for entering a $\mathrm{PhD}$ program.

In their individual e-portfolios students place the materials reflecting their achievements in educational, public, professional, scientific and other activities during the study. The main thing is demonstrating the results of different practices (practice reports, teachers' feedback, reflexive materials, videos, photo reports, etc.). Eportfolios are used by graduates to present them to potential employers. To create eportfolios the resources of SibFU's official website [35], the IEPS's official website [37] and Mahara (English application) [21] are used. The examples of e-portfolios of the future teachers of IEPS SibFU are shown in Fig. 2. 


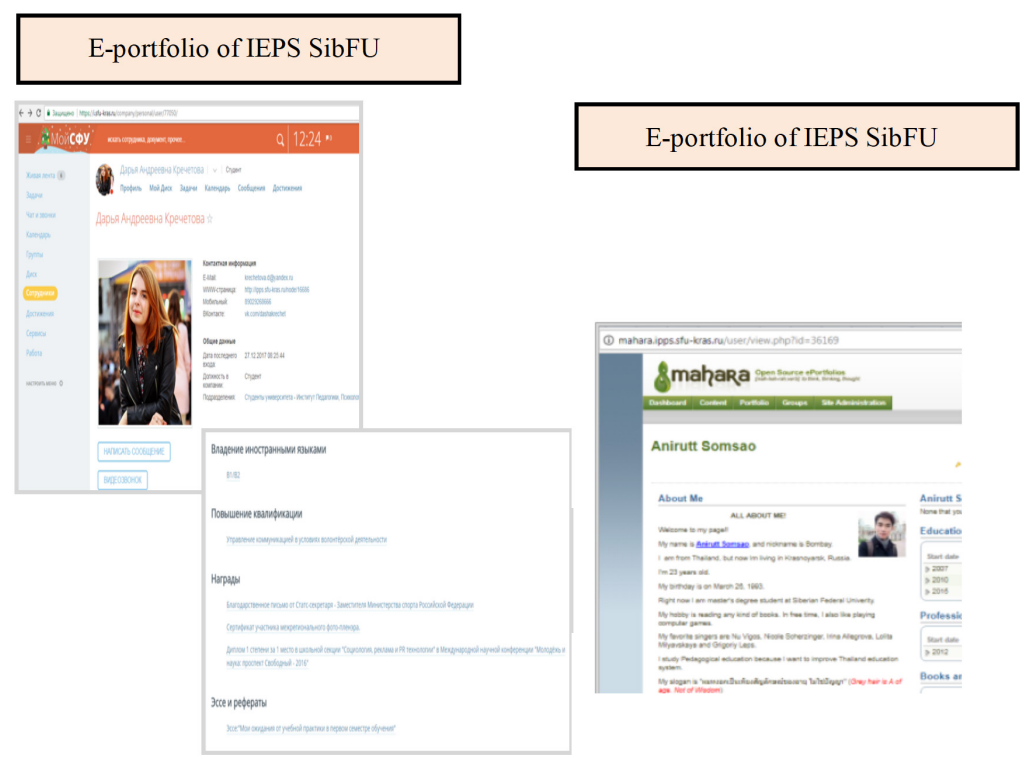

Fig. 2. Examples of students' e-portfolios of the pedagogical directions of IEPS SibFU

E-portfolio technology means a significant element in the digital environment of the federal university. Implementation of a mixed learning model with electronic educational environments contributes to the arrangement of students' independent work, supports interactivity and continuity of learning. A successful completion of control and assessment of this e-learning by the experts of an independent "Agency Quality Assurance in Higher Education and Career Development" (AKKORK) [3] confirmed the effectiveness of e-portfolio technology and e-learning implementation at SibFU. This procedure was carried out regarding the requirements and criteria established by the European Foundation for Quality in E-learning (EFQUEL). The bachelor's and master's degree programs of the IEPS at SibFU have become the object of this international assessment due to active introduction of the modern technologies into the educational process, partial participation in the informational support of the university's activities and development of e-learning at the university [28]. Certain changes in educational technologies are associated with a systematic use of the ICT in the information and educational environment of the university (LMS systems of MOODLE, e-portfolio technologies, e-learning systems).

\subsection{Digital laboratory of IEPS at SibFU. PROLog module system of experiments}

Since 2013 the digital laboratory of IEPS at SibFU which practices PROLog module system of experiments has been opened. This laboratory introduces innovative training equipment for a large number of demonstrations, researches, experiments and laboratory work, as stated in [18]. The use of digital laboratories in the educational process makes it possible to change the attitude of students to the subject itself, to 
learn the subject from its practical side, and, therefore, to increase interest in the academic subject. In addition, digital laboratories allow students to learn how to collect numerical and audiovisual data in natural science observations and experiments using sensors, to form their skills of independent search, selection and analysis of information.

According to the researchers [19], it is necessary to use integrated technologies in the modern educational process, including web-based technologies.

We will present a learning model based on educational equipment of primary school cabinet, subject offices of educational institutions developed by "Prosveschenie" and "Drofa" publishing houses as shown in Fig. 3. This model was regarded as a basis for equipping the digital laboratory of IEPS at SibFU.

Such set of training tools is formed on the basis of the following principles:

- Attention to psychological and pedagogical features of the age;

- Combination of innovative (based on digital technologies) and traditional (printed materials, natural objects, models, etc.) learning tools;

- Relevance in using training tools for the educational process;

- Universality and possibility of using the same training tools to tackle a set of tasks in educational and extracurricular activities and in different subject areas, using a wide range of training methods;

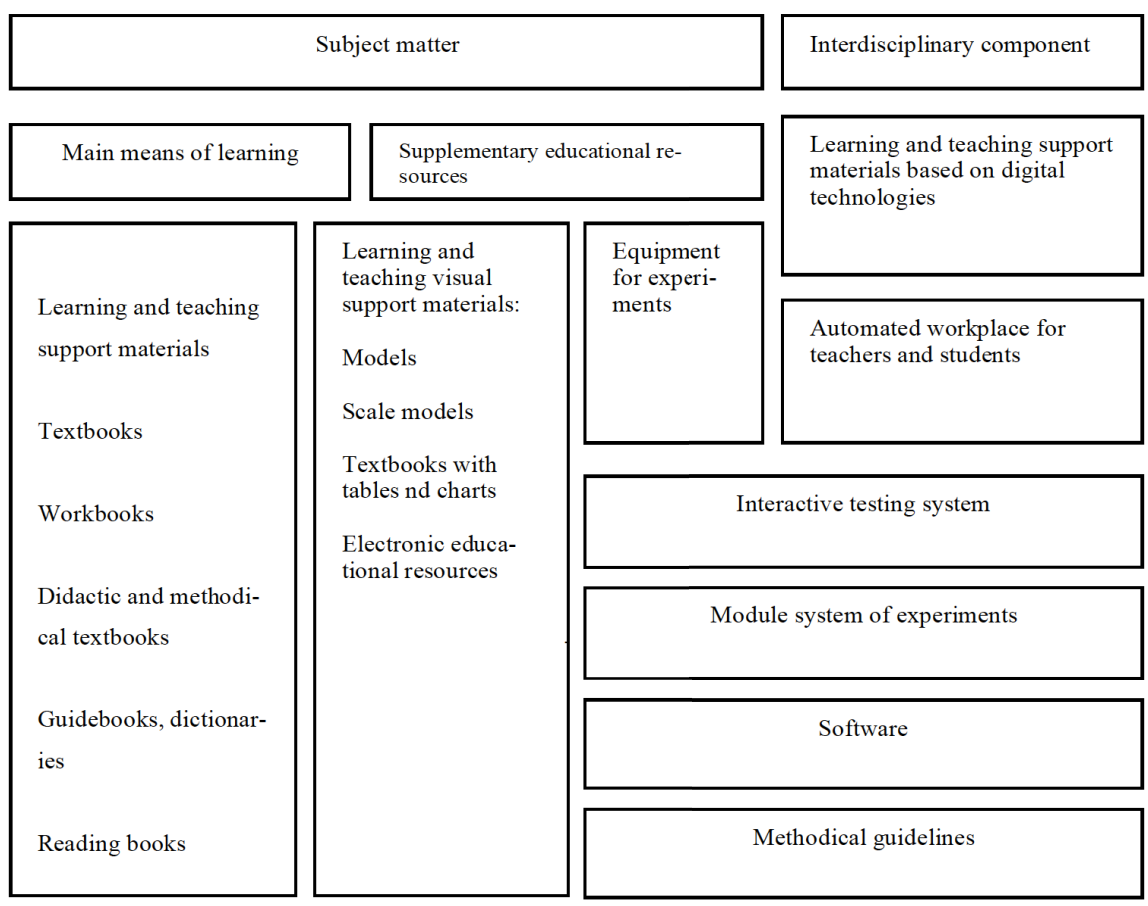

Fig. 3. Learning model with using a digital subject laboratory for primary school [39] 
- Providing ergonomic operational mode for all the participants of the educational process;

- Consistency in sharing the digital equipment as stated in [7].

A set of training tools provides:

- Organization of information and educational environment at the educational institution;

- Grasping the basic educational program of general education by all students;

- Use of modern active educational technologies in the educational process;

- Identification and development of students' abilities (building and implementing individual educational paths; working with talented children);

- Organization of scientific and technical creativity alongside with design and research activities;

- Organization of productive students' individual work in searching and acquiring knowledge and skills that meet the requirements of the information society;

- Rational use of the training time by automating of certain professional tasks.

The modern system of learning and teaching support materials is realized in the form of automated workplaces (AWP) for the teacher and students - a set of innovative and traditional learning and teaching support materials with methodical guidelines and refresher courses modules for their using in the educational process.

Innovative learning and teaching support materials include:

- Hardware - a module of large-scale visualization, information management and replication, organization of effective interaction between all participants of the educational process; document camera, module system of experiments and digital microscope; management system for the quality of knowledge;

- Software - part-preinstalled multi-user operating system and application software;

- E-learning resources in subject areas.

Traditional learning and teaching support materials in subject areas contain different means of visualization, laboratory equipment, instruments for conducting live experiments, etc.

They are used independently and together with innovative learning and teaching support materials, increasing their functionality and efficiency in the educational process.

The laboratory of IEPS at SibFU AWP is a professionally oriented set of software and hardware tools integrated into a comprehensive solution, implied in the informative and educational environment of the educational institution and designed to automate learning, pedagogic and administrative activities of the teacher (Fig. 4). 


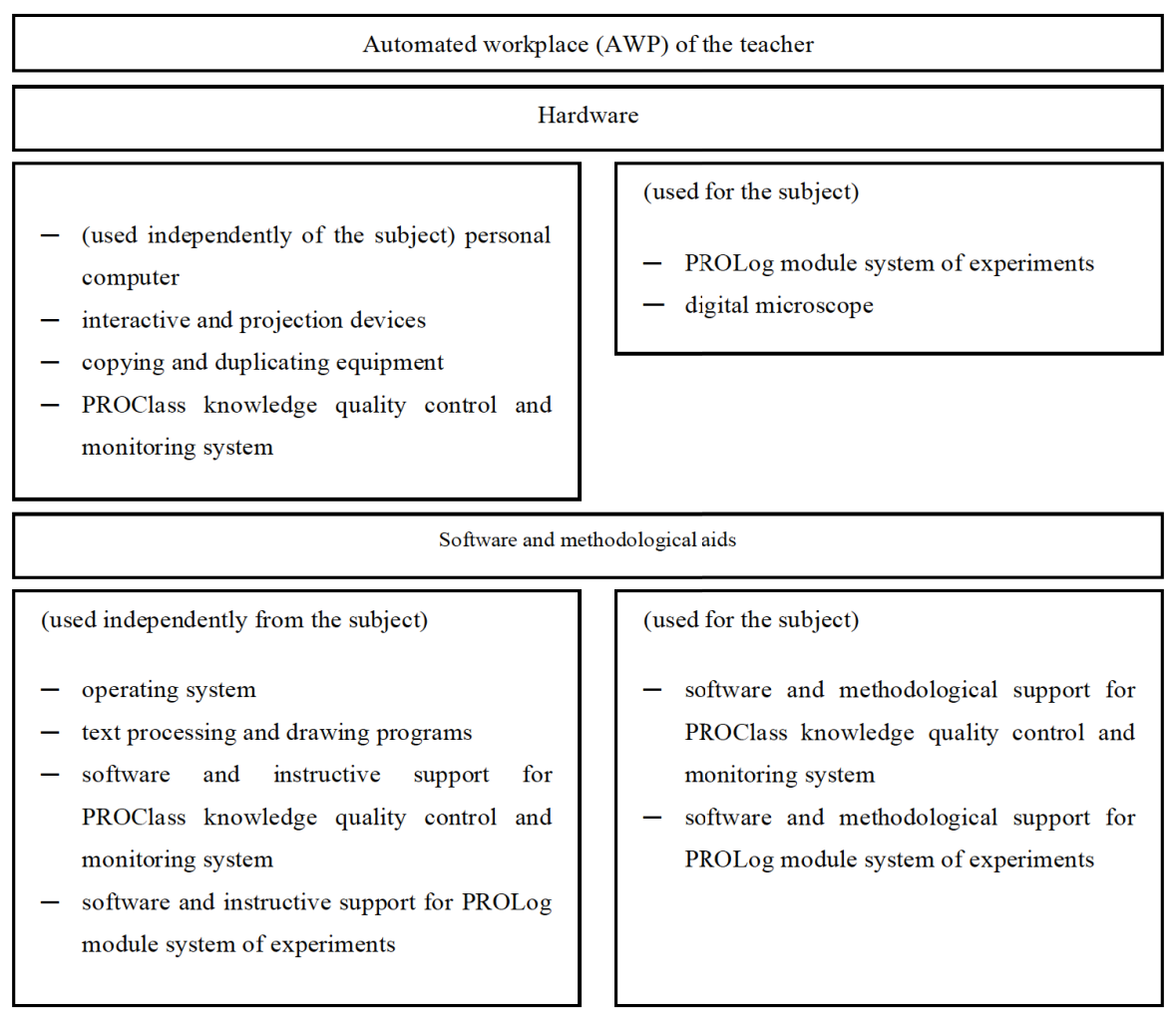

Fig. 4. Automated workplace of the teacher in the laboratory of IEPS SibFU

The teacher's AWP in the laboratory of IEPS at SibFU consists of hardware component, software component and guidance materials.

The hardware component of teacher's workplace in this digital laboratory is presented in Fig. 5. The main components are: laptop, smart board with software, projector, Ken-a-Vision document camera with software, multifunctional device (printer/scanner/copier), PROClass knowledge quality control and monitoring system with basic software, PROLog module system of experiments with basic software and digital microscope.

The software component of the teacher's workplace in the digital laboratory consists of:

- System software (Microsoft Windows 7);

- PROClass software with an integrated set of control tests (presentations) on various topics of the subject;

- Software for PROLog module system of experiments with an integrated set of laboratory work on various topics of the subject. 


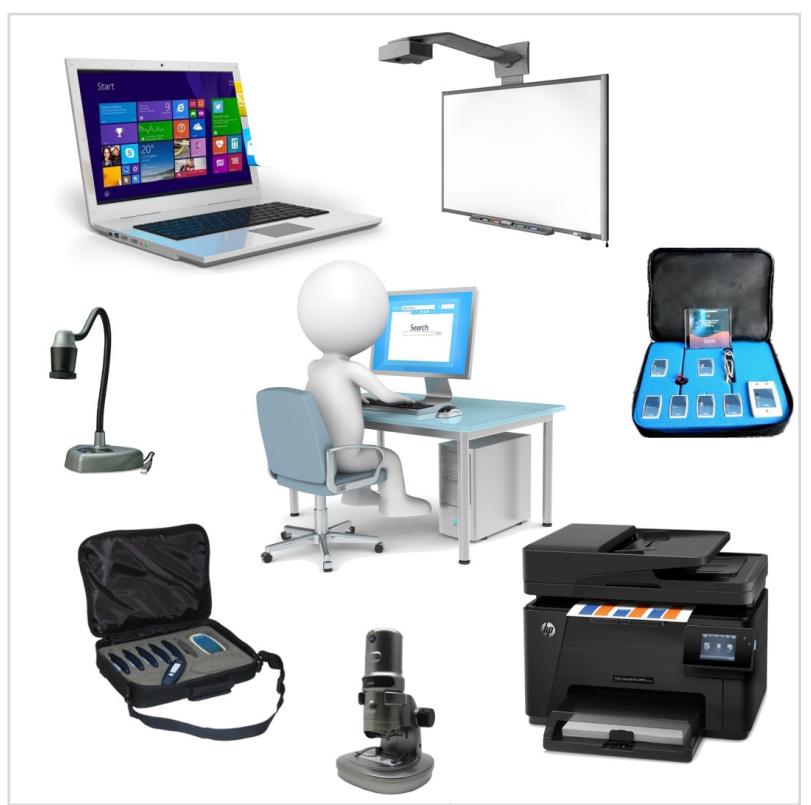

Fig. 5. The scheme of the teacher' workplace in the digital laboratory of IEPS SibFU

Student's AWP in the laboratory of IEPS at SibFU represents a collection of hardware and software that is integrated in the informative and educational environment of educational institution and designed to optimize students' cognitive activities.

The student's AWP consists of hardware component, software component and guidance materials. The hardware part is represented by a base for recharging and storing laptops, an external optical drive DVD-RW (USB), PROLog module system of experiments with basic software and digital microscope. Unlike the software component for the teacher, the student's place is equipped only with the system software and necessary software for PROLog module system of experiments with an integrated set of laboratory works (not less than 10) on various topics of the subject.

The would-be teachers and tutors cover one of the most efficient systems among digital laboratories - PROLog module system of experiments (Fig. 6). Before entering the pedagogical practice, students conduct educational experiments, study methods of data processing and construction of experiments not only in the classroom but also on fields that is especially important for researches in natural sciences. In this case the measurement results are processed and analyzed directly during operation without a PC connection or stored in the memory for further processing and researching on the PC.

The PROLog module system of experiments is a hardware and software complex that provides collection and processing of experimental data from various disciplines during the natural science course in primary and secondary schools, providing modern methodological and research components of the training. 


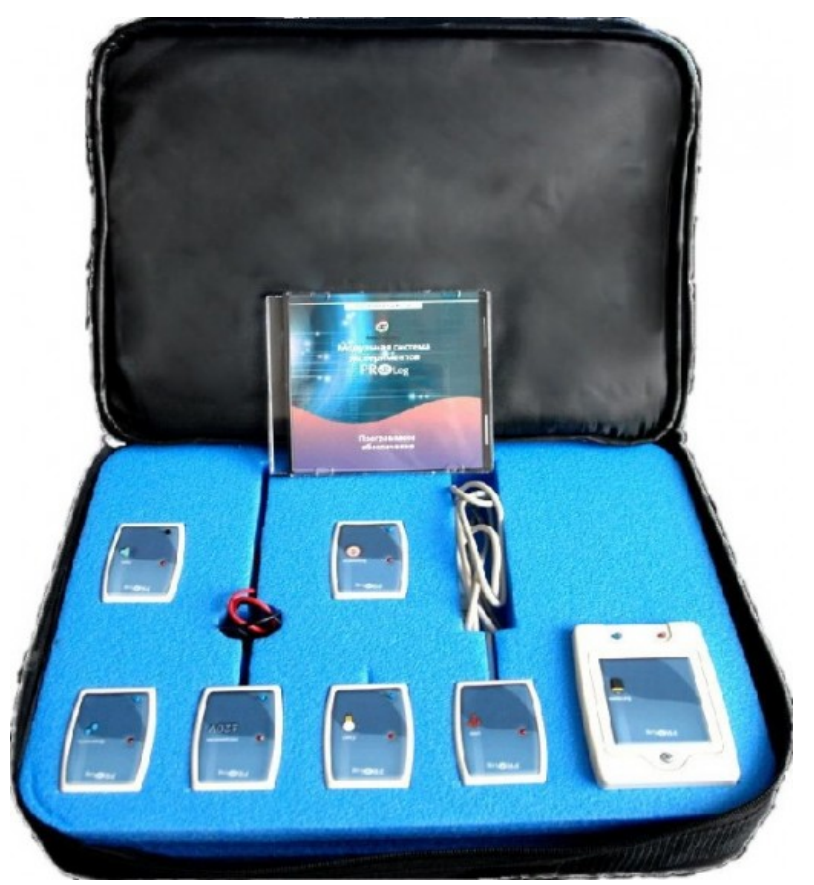

Fig. 6. PROLog module system of experiments[30]

The advantage of PROLog system lies in the autonomy of digital measurement modules (DMM), each of which can be considered as a separate data logger which allows recording and storing the measurement results independently of each other. The system includes devices for reading, processing and visualization of information:

- Personal computer;

- Modules which display graphical information - MDGI;

- Modules which display numerical information - MDNI.

Each DMM has a microprocessor that measures and records the findings (e.g. temperature, amperage, voltage) into its own memory independently of other modules and information readout device.

The PROLog software is used to operate the system with the PC.

The digital modules of the PROLog system have two modes:

- Experiment in a direct mode (experiment with interrelated modules, online experiment), i. e. when connected to a PC or MDGI;

- Experiment in an autonomous mode (autonomous experiment, offline experiment).

In the "Experiment in direct mode" the PC or MDGI controls the experiment: when, how and what to measure, how often, how long, etc. In this mode the information is received by the PC or MDGI and displayed in real time. 
In the "Experiment in autonomous mode" DMM with the help of PC or MDGI are pre-programmed according to the experiment objectives. The assessment starts by clicking the button "Start" on each module or by clicking the button "Measure" in the additional toolbar of the program. In this case, all connected DMMs are launched simultaneously. The measurements are stored in the internal storage of each DMM for further reading and displaying on the PC or MDGI.

Thanks to such identification system, several modules of the same type (up to nine) with different IDs can be connected to the same DMM chain. At the same time, if you use the program to configure DMM to measure different environmental parameters (for example, the air temperature in the street, in the room and in a vessel with boiling water at the same time), as a result, you can get more complete picture of the experiment, discuss the collected data with students, formulate project reports and implement a problematic approach in learning.

The modules which display information: graphical and numerical

Graphical or numerical modules which display information (MDGI or MDNI) are used for the experiments without PCs. MDGI or MDNI are extremely useful in cases where there is no access to computer for all students in the group at the same time and when they work outside the classroom. MDGI shows the measurements in graphics, while MDNI - only in numerical form. MDGI is also used to program the settings of module parameters within the experiment. MDGI or MDNI allow controlling the connection of modules in accordance with the experiment program, as well as showing the data measured by DMM. MDGI has colored LCD touch screen and MDNI has LCD screen.

The digital measurement modules also include the interface module, battery module, module "Temperature", "Sound", "Light", "Humidity", "Air pressure (barometer)" and the wireless communication module.

The wireless communication module allows transferring the measurements directly from DMM wirelessly to the information display module (numerical or graphical) or computer; the system allows organizing simultaneous work of the students' group (up to 9 people) on the basis of one PC, which is especially important in schools with limited number of computers; it can be connected up to 50 DMMs to one USB input, each DMM can be configured for your experiment, with its properties (mode and frequency of measurement as well as the experiment's period).

All this provides unique opportunities to conduct teaching experiments and to implement students' training projects.

PROLog "Module system of experiments" software is designed to create a set of experimental studies in various disciplines and is used to conduct experiments in a lesson, extracurricular and project activities for the students of secondary schools, institutions of primary, secondary and higher education. PROLog software allows video-recording experiments and synchronizing them with the collected data; provides processing, data saving and visual presentation of the results in graphics and/or tables; provides data saving, export to Excel, possibility to print them [6].

Unlike other sensor systems, the PROLog module system of experiments has the following advantages: 
- New technical solutions in the design of measuring modules which are both sensor and digital signal converters;

- Each measuring module can operate in three modes: autonomous, with graphical and / or numerical display modules, with PC;

- Numerical module which displays measurements of all connected DMMs (in turns);

- Graphical module which displays measurements and includes programming for independent work;

- Several experiments results (up to 5) after they are carried out and disconnected, i.e. stored in the memory of the module for a long time.

\section{$4 \quad$ Experience}

Within the framework of the digital laboratory the students of "Pedagogical education" course in the IEPS at SibFU have conducted an experiment using the PROLog system in primary school to organize individual and group research work for younger pupils on natural science within "World around us" lessons.

The study has been carried out in 2 formats:

- Express researches (pupils quickly conduct short-term researches on the proposed topics);

- Long-term researches (pupils or a small group of students perform researches on the proposed algorithm).

Long-term researches in primary school with the use of PROLog system are implemented with the help of this scheme:

- Problem statement;

- Possible solutions offering;

- Gathering all the material necessary for the experiment;

- Summarizing the results;

- Students' full name for the experiment.

Within the study involving the use of PROLog module system specially designed in Russian schools, the current experience alongside with the gained data have been analyzed. The review of references has demonstrated that up to this moment there is no comprehended description of PROLog implementation in the future teachers training [24], [17], [38] that also may evidence the relevance of this research.

PROLog module system of experiments allows pupils to observe the world around them, study and explore it by doing model experiments by the temperature module. Owing to this experiment, the children have studied the phenomena and laws of thermodynamics. Before the experiment they formulated the questions: "Why is it warm in mittens? Why does ice melt? Why does water boil? When is it warm in the classroom - in the afternoon or at night? What secret is hidden in the sole? Why does the 
liquid in the thermos stay hot for a long time?" The problem is based on the material available for this age.

The modules of air pressure, humidity and temperature have given children an opportunity to assemble a small meteorological station and monitor the weather. The sound module has helped to study the world of sounds, to understand what noise is and why it is quieter in the forest, rather than next to the road. By working with the equipment module, the children have learnt and clearly seen the impact of light on plants; they could measure the light level in the classroom and in the school yard, understand what light and shadow are. The results of the experiment in the elementary school using the PROLog system are exemplified in Fig. 7.

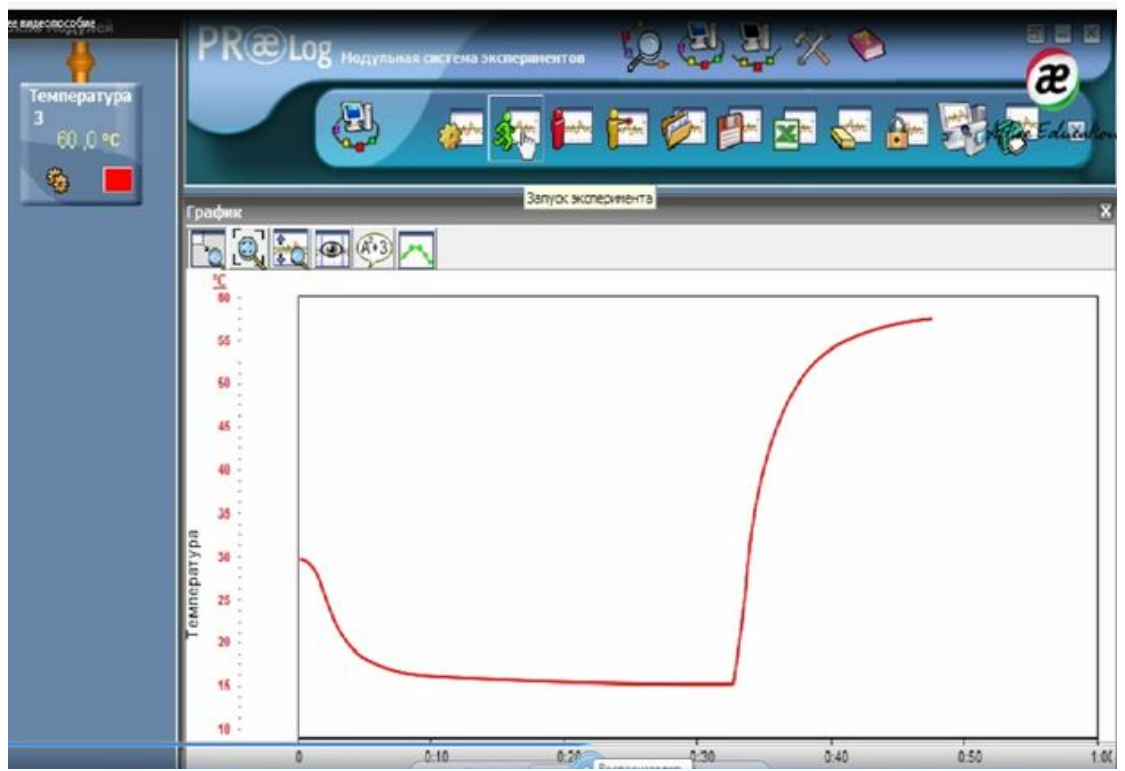

Fig. 7. Results of using PROLog module system of experiments in primary school

The use of PROLog module system of experiments has led to higher results in research activity of the students. Within the practical training through the digital laboratory the students have taught junior schoolchildren different topics in the course of "The World Around Us". Due to the function of data storage and transferring in the digital laboratory, they both have referred to the results of previous experiments, comparing those results with the new data on-line. PROLog module system has, in turn, allowed the trainees to succeed in organizing and maintaining independent research practices of the junior schoolchildren and provided an active feedback system for all the participants, i.e. students, schoolchildren and teachers.

We have questioned 63 teachers including those who work at the Federal University and school teachers as well, and the results have proved the efficiency of PROLog module system in education. The findings are added in the Table 1. 
Paper-Implementing Teachers' Training Technologies at a Federal University...

Table 1. The survey data on the use of PROLog module system in organizing schoolchildren' research activity

\begin{tabular}{|l|c|}
\hline $\begin{array}{l}\text { Has the use of PROLog module system influenced the schoolchildren' research activity } \\
\text { arrangement? }\end{array}$ & Per cent \\
\hline $\begin{array}{l}\text { Yes, it has improved the process of monitoring of their research results and better organize } \\
\text { the feedback system }\end{array}$ & 40 \\
\hline Yes, the experiment time has been cut & 33 \\
\hline Yes, the schoolchildren have been highly motivated during the research activity & 26 \\
\hline To be undecided & 1 \\
\hline Total & 100 \\
\hline
\end{tabular}

The results of the experiments carried out through the online and offline modes by the means of digital laboratory of the IEPS at SibFU have been published by the students in their e-portfolios. The necessary learning and teaching support materials have been received when passing an electronic training course in the LMS Moodle in SibFU's system. In prospects, this allows them to:

- Compare the data obtained during the research in the framework of the course and diploma projects;

- Use the obtained results while defending their individual e-portfolios created with the help of various SibFU's electronic resources within individual disciplines or educational practices;

- Use their publications in individual e-portfolios when passing the final exams with the representatives of professional communities and employers;

- Demonstrate their individual e-portfolio with the published results on scientific experiments when applying for a position in educational institutions.

The model of using the digital laboratory of IEPS at SibFU is shown in Fig.8. This model is based on the scientific researches [19], [13], [16], [20] on using the cycle of David A. Kolb [5].

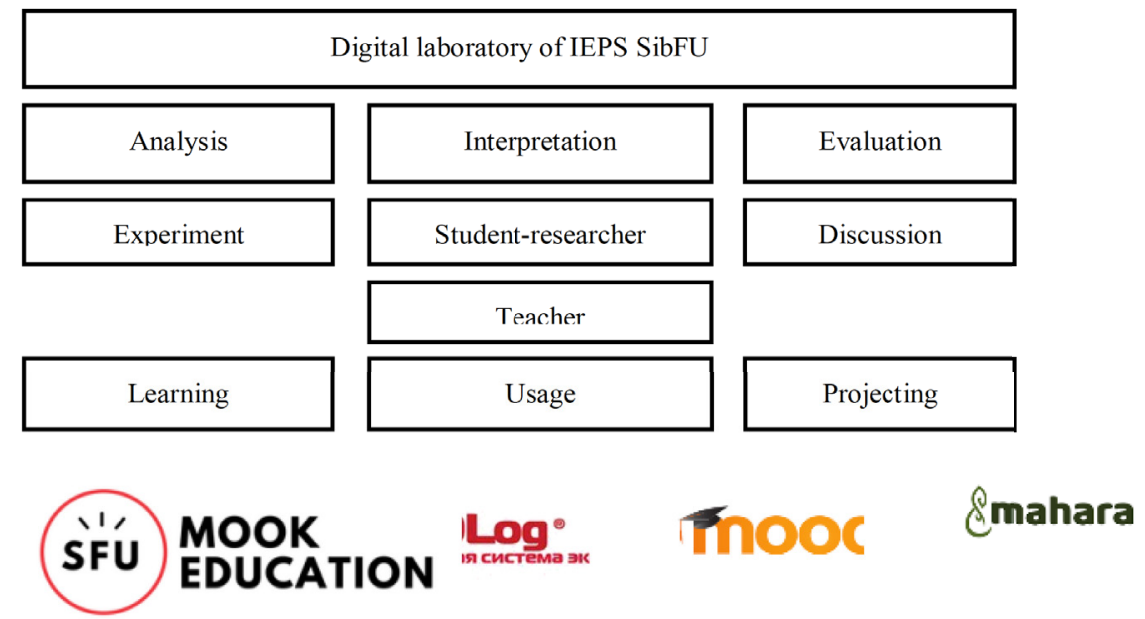

Fig. 8. The model of using the digital laboratory of IEPS SibFU 
At the end of pedagogical modeling we have considered the opinion of students and faculty of the Federal University about whether it is relevant to use the modern digital technologies in education. The survey has been conducted through the Googleform and received the responses of 109 students and 63 teachers. The comparison of the corresponding results is shown in the Table 2.

Table 2. The results of survey among the students and teachers on the efficiency of modern pedagogical technologies (e-portfolio, digital laboratory, PROLog module system) in the process of training at the Federal University

\begin{tabular}{|c|c|c|}
\hline $\begin{array}{l}\text { Implementation of E-portfolio, Digital Laboratory, PROLog Module System in } \\
\text { the future teachers training has introduced }\end{array}$ & \multicolumn{2}{|c|}{ Per cent } \\
\hline \multirow{2}{*}{$\begin{array}{l}\text { 1.Efficient assessment and monitoring of students' activity and teachers' } \\
\text { performance }\end{array}$} & Students & Teachers \\
\hline & 15 & 16 \\
\hline 2. Academic satisfaction & 15 & 11 \\
\hline 3.Positive reinforcement of students & 11 & 10 \\
\hline 4.Efficient feedback system implementation & 11 & 10 \\
\hline 5. Reward management in the training process & 8 & 13 \\
\hline 6. Information storage security, personal privacy & 8 & 5 \\
\hline 7.Mastering of reflection and self-reflection & 7 & 7 \\
\hline 8.Proper academic support of the learning process & 8 & 9 \\
\hline $\begin{array}{l}\text { 9. Utility of interactive learning technologies, various contents and digital } \\
\text { education resources }\end{array}$ & 9 & 12 \\
\hline 10. Personalized education results & 7 & 7 \\
\hline To be undecided & 1 & 0 \\
\hline Total & 100 & 100 \\
\hline
\end{tabular}

These findings have shown that the students $(15 \%)$ and teachers $(16 \%)$ consider the use of e-portfolio, digital laboratory and PROLog module system used in the future teachers training as an efficient tool while assessing and monitoring the students' activity and teachers' work. The majority of students (15\%) and teachers $(11 \%)$ have also been highly satisfied with the application of modern pedagogical technologies in the learning process at the Federal University. The importance of these technologies in academic and individual work reinforcement as well as of the feedback system implementation has been also mentioned by the students $(11 \%$ for each point accordingly). Among other significant advantages of these technologies, the teachers have pointed out the reward system realization in the learning process $(13 \%)$ and relevance of interactive education technologies, various contents and digital education resources $(12 \%)$. It is worth mentioning, that the smallest number of teachers has noticed the information storage security and personal privacy $(5 \%)$ when using e-portfolio, digital laboratory and PROLog module system. This problem may well become another issue to focus on further.

\section{Conclusion}

The research has been aimed at improving the quality of teachers training through the use of e-learning, digital laboratory of scientific experiments modeling for elementary school and academic performance assessment technologies with the means of e-portfolio. The use of e-portfolio and PROLog module system of experiments at the 
digital laboratory of IEPS at SibFU has ensured a good realization of e-learning and development of the digital environment in the Federal University. The students have been intensively engaged with other participants of the learning process off- and nline. They, thus, have conducted a number of learning experiments in and outside the classrooms, i.e. in the places of their teaching practicum, in schools and nature. The findings have been posted on their personal e-portfolios that has, in turn, led to their IT skills mastering. Moreover, as a part of the IEPS's laboratory, the students have analyzed the calculations during the experiment and on-line. The skills of working with PROLog set in the digital laboratory of IEPS at SibFU have provided the future teachers with an opportunity to use it in their professional activity. In this way, the research has confirmed the efficiency of modern teaching technologies implementation (E-portfolio, Digital Laboratory, PROLog Module System) in the training of future teachers at the Federal University. The students together with the faculty have been extremely satisfied while using these technologies in learning by noting advantages of the feedback system and academic assessment and monitoring. The main ideas of this research may well be further developed into another study in the sphere of future teachers training development.

\section{References}

[1] A.L. Semenov, "On fundamental concepts of cybernetics and computer science", Proceedings in Cybernetics, vol.3, no. 19, pp. 22 - 26. 2015.

[2] A.V. Khutorskoy, Didactics. Textbook for higher education. $3^{\text {rd }}$ educational standard, Saint-Petersburg: Piter Publishing House. 2017.

[3] Agency Quality Assurance in Higher Education and Career Development, available at http://www.akkork.ru/e/about/.

[4] Credit on the results of MOOC at SibFU, available at http://edu.sfu-kras.ru/elearning/opencourses-credit

[5] D.A. Kolb, Experiential learning: experience as the source of learning and development. $2^{\text {nd }}$ edition, Pearson FT Press, pp. 416. 2014.

[6] E. M. Kosmina, "The use of PROLog system", available at http://nsportal.ru/nachalnayashkola/informatika/2014/03/31/ispolzovanie-sistemy-prolog. 2014.

[7] E. A. Balyko, "Automated workplace of the teacher: a practical guide", available at http://edubrends.ru/products/primaryschool/ps-ss_digitlabs.html

[8] E-learning at SibFU, available at http://edu.sfu-kras.ru/elearning

[9] E-learning system of SibFU, available at https://e.sfu-kras.ru/login/index.php

[10] Federal Law № 273-FZ on the 29 $9^{\text {th }}$ December, 2012 "On Education in the Russian Federation", available at http://zakon-ob-obrazovanii.ru/

[11] I. V. Robert, The theory and methodology of learning process informatization (psychopedagogical nad technological aspects), Moscow: BINOM. Laboratory of Knowledge. 2014.

[12] I. V. Zhilavskaya, "Media and information literacy: a new concept" available at http://www.ifapcom.ru/files/2015/mil_rus/mil_rus_2013.pdf. 2015.

[13] I.B.N. Sudria, I W.Redhana, I M.Kirna, D. Aini, "Effect of Kolb's Learning Styles under Inductive Guided-Inquiry Learning on Learning Outcomes", Int. J. of Instruction, vol. 11, no.1, pp. 89-102. https://doi.org/10.12973/iji.2018.1117a 
Paper-Implementing Teachers' Training Technologies at a Federal University...

[14] Information for all Programs, available at https://en.unesco.org/site s/default/files/2771_17_ci_en_ifap_web_final.pdf

[15] International online-conference "Digital education for the digital economics" at Moscow State Pedagogical University, available at http://mpgu.su/novosti/tsifrovoe-obrazovaniedlya-tsifrovoy-ekonomiki-rezultatyi-mezhdunarodnoy-online-konferentsii/. 2017.

[16] J. Koob, J. Funk, “Kolb's Learning Style Inventory: Issues of Reliability and Validity”, Research on Social Work Practice, vo. 12, no.2, pp. 293 - 308. https://doi.org/10.1177/ 104973150201200206

[17] L.V. Chernykh, "PROLog module system as a means of students' academic and research activity implementation", Proc. Of $2^{\text {nd }}$ All-Russian Festival on Pedagogics "Contemporary Methods and Techniques in Education", available at: http://naukait.ru/attachments/article/1919/chernyh_lv_staronikolskoe_fest14.pdf. 2014.

[18] M. A. Petrova, "Information and educational environment as the means of implementing the requirements of FSES", available at https://ido.mgpu.ru/materials/29/29780.pdf

[19] M. Gourmaj, A. Naddami, A. Fahli, D. Nehari, "Teaching power electronics and digital electronics using personal learning environments", From Traditional Learning to Remote Experiential Learning, vol. 13, no.08, https://doi.org/10.3991/ijoe.v13i08.6840

[20] M.V. Klarin, "Corporate education: goals and features", Bul. of Buryat State University. Education. Person. Society, vol.1, pp. $6-16$, http://journals.bsu.ru/conten t/files/articles/article 190.pdf. 2016.

[21] Mahara (English application), available at http://mahara.ipps.sfu-kras.ru.

[22] N. I. Gendina, Information training and media education in Russia and CIS countries: formation issues of informational culture of personality and promotion of information and media literacy ideas, Saarbrucken: Lambert Academic Publishing, 186 P., 2012.

[23] N.R. Azizova, N.A. Savotina, et al, Developing professional pedagogical competence. Multicultural and informational competence: study guide, Moscow: Urait Publishing Center, 2018.

[24] O. A. Beshkareva, "The use of informational and communicational technologies during class and extra activity on physics", Proc. Of International Applied Science Conference "Topical Problems of Education in Science and Mathematics", pp. 143 - 146. 2016

[25] O. G. Smolyaninova, Problem of assessment of educational achievements: e-portfolio technology: monograph. Krasnoyarsk. 2015.

[26] O. G. Smolyaninova, "Problem of evaluation of educational achievements: e-portfolio technology", Information and Education, vol. 1, pp. 55-63. 2016.

[27] O.G. Smolyaninova, "E-portfolios in teacher education in Russia: pathway from assessment to professional development", Proc. Eighth Int.Technology, Education and Development Conf. (INTED 2014), pp. 6058 - 6064, Mar. 2014.

[28] O.G. Smolyaninova, E.A. Bezyzvestnykh, "E-portfolio technology in evaluation of students' formal, non-formal and informal learning. Accreditation of Educational Programs and Development of E-learning in a Federal University". Proc. Of 10th Int. Technology, Education and Development Conference (INTED 2016), pp. 0614 - 0619.

[29] Open education platform of the Russian Federation, available at https://openedu.ru/

[30] Participation of adult population in lifelong education. Monitoring of economics of education information and analytical materials on the results of sociological survey, no. 2, available at https://www.hse.ru/data/2015/03/25/1234016904/ВГ-образование-монпрезент.pdf. 2015.

[31] Personal account in SibFU, available at https://i.sfu-kras.ru/ 
Paper-Implementing Teachers' Training Technologies at a Federal University...

[32] Primary and secondary school equipment. Digital laboratories, available at http://edubrends.ru/products/primaryschool/ps-ss digitlabs.html

[33] Priority project "Modern digital educational environment in the Russian Federation", available at http://минобрнауки.рф/проекты/современная-цифровая-образовательнаясреда

[34] Regulations on e-learning and distance learning technologies implementation in SibFU, available at http://about.sfu-kras.ru/docs/9739/pdf/926831. 2017.

[35] Resource for creating e-portfolio, available at https://i.sfu-kras.ru/

[36] Service to manage your personal account, available at https://users.sfu-kras.ru/

[37] Students' e-portfolios in the IEPS at SibFU, available at http://ipps.sfu-kras.ru/students

[38] T.A. Lescheva. "Use of PROLog digital laboratory during "The World Around Us" classes", available at: https://infourok.ru/statya-ispolzovanie-cifrovoy-laboratorii-prolog-naurokah-okruzhayuschego-mira-270898.html. 2015

[39] The list of the educational equipment for primary school classroms, educational institutions classrooms, available at http://www.komobr46.ru/text\%20doc/news/perechen prosv region.pdf.

[40] The percentage of respondents

[41] V. V. Grinshkun, "On actual aspects of teachers' training in the field of informational support of education", Bul. of RUDN University. Section: Informational support of education, vol. 4, pp. 7-12. 2015.

[42] Webinars and video conferences service, available at https://webinar.sfu-kras.ru/

\section{$7 \quad$ Authors}

Olga Smolyaninova is with Siberian Federal University, Krasnoyarsk, Russian Federation (ippssfu@mail.ru),

Ekaterina Bezyzvestnykh is with Siberian Federal University, Krasnoyarsk, Russian Federation (ipps_sfu@sfu-kras.ru)

Article submitted 27 July 2018. Resubmitted 20 October 2018. Final acceptance 20 January 2019. Final version published as submitted by the authors. 